\title{
Care and Support of Children with Type 1 Diabetes at School: The Turkish Experience
}

\author{
(1) Şükrü Hatun1,2, (1) Gül Yeşiltepe Mutlư1, (1) Tuğba Gökçe1, (1) Özkan Avcı33, (1) Nazan Yardım4, (1) Zehra Aycan5, \\ (1) Feyza Darendeliler6
}

${ }^{1}$ Koç University Faculty of Medicine, Department of Pediatric Endocrinology and Diabetes, İstanbul, Turkey

${ }^{2}$ Koç University Faculty of Medicine, Coordinator of Diabetes Program, Istanbul, Turkey

${ }^{3}$ Republic of Turkey Ministry of National Education, General Directorate of Support Services, Ankara, Turkey

${ }^{4}$ Ministry of Health of Turkey, General Directorate of Public Health, Ankara, Turkey

${ }^{5}$ Ankara University Faculty of Medicine, Department of Pediatric Endocrinology, Ankara, Turkey

6istanbul University, İstanbul Faculty of Medicine, Department of Pediatric Endocrinology, İstanbul, Turkey

\begin{abstract}
Diabetes care at school has recently appeared on the agenda of international diabetes organizations, the basic principles of which have been newly determined. The aim of this review was to summarize the activities and output of the Diabetes at School Program - a program that has been delivered in Turkey for the last 10 years - and to focus on different aspects of Diabetes Care at School through a national model. Recently, a detailed set of national regulations, including the basic principles proposed by the International Society for Pediatric and Adolescent Diabetes and the experience in Turkey, was prepared and has come into force. The future agenda includes giving priority to socio-economically disadvantaged regions, provision of an Individual Treatment Plan at School for each child with diabetes and ensuring that each school has an action plan for the care of children with diabetes. We believe that if all countries have programs and structured national regulations similar to the Diabetes at School Program, this will enable significant progress in the level of care delivered to children with diabetes.
\end{abstract}

Keywords: Type 1 diabetes, children, school, program

\section{Introduction}

Once a child of school-age is diagnosed with type 1 diabetes (T1D), this becomes a problem and a concern not only for the child, but, as might be expected, also for the whole family. The first problem encountered by parents and caregivers is the difficulties associated with organizing their child/children's school life. Today, in almost all countries, there is a significant gap between the arrangements needed to maintain the routines of diabetes care such as insulin therapy, nutrition and carbohydrate counting, management of emergencies including hypoglycemia, correction boluses to keep glucose in the target range, and so on and the capabilities and facilities available at school. This challenge has persisted since 2009 when Lange et al (1) described this gap as "disturbing facts" in their article (2).
In countries like Turkey, this gap has long been one of the most important problems in diabetes care, and families, especially mothers, bear the burden of diabetes care at school (3). However, in addition to achieving the goal of having a 'Time in Range' proportion of $70 \%$ and above, a goal which has become important in recent years, it is also a priority to organize a plan that integrates diabetes care into school in such a way as to increase the school performance, including mathematics test scores, of children with T1D $(4,5)$.

In recent years the International Society for Children and Adolescent Diabetes (ISPAD) and the International Diabetes Federation (IDF) have focused on diabetes care at school. The consensus document published by ISPAD in 2018 has been an important step in this regard $(6,7)$. Based on this 
document, recommendations of other diabetes-related organizations and expert opinions, the principles of diabetes care at school are summarized in Table $1(2,8,9)$. This article aims to share the evolution of the "Diabetes at School Program" that has been operational in Turkey for 10 years and to emphasize and develop the latest recommendations on diabetes care at school.

\section{The Diabetes at School Program: History and Main Activities}

In Turkey there are approximately 20,000 children under the age of 18 living with T1D. It has been estimated that at least 15,000 of them are of school age (10). As in many countries, it is known that children with diabetes face significant issues at school and that the knowledge of teachers and school staff about T1D and daily treatment routines is insufficient $(11,12)$. Moreover, poor knowledge of T1D and delays in diagnosis due to other reasons are still important problems, both in school and out. Consequently, the frequency of

Table 1. The principles of diabetes care at school based on ISPAD recommendations (6)

Proper diabetes management at school is a prerequisite for successful school performance and avoiding medical complications.

It is of importance to provide blood glucose levels within the target range during school hours, and daily blood glucose targets should not vary with a change in environment.

It should be ensured that children with T1D participate in school life on an equal basis with their peers.

Families cannot be expected to remain in school all day long to monitor blood glucose and administer insulin injections. The requirements for glucose monitoring and insulin administration should be met by someone other than a family member.

Immediate treatment of hypoglycemia should be provided.

Healthy eating options should be provided in the schools.

The pediatric endocrinology and diabetes centers should cooperate with the family to prepare an "Individual Treatment Plan for School" document for each child with T1D and this document should be delivered to the school administration with an official letter. This document should be updated annually.

All the school staff, including teachers, administrators, and school nurses should be trained to support the implementation of daily diabetes care routines.

There should be legislation for diabetes care at school, detailing the principles, responsibilities, and duties at a national level.

In order to provide the transition of a child with T1D to a selfmanagement process in diabetes care, there should be a supportive plan appropriate for her development, and support should be provided in the school environment.

There should be an action plan in the school for every child with T1D and the school administration should designate the school nurse, if any, or another school staff member as being responsible for coordination.

The value of close cooperation between the child and stakeholders such as the school nurse, teachers, school administration, family, and the diabetes center where the child is monitored should always be kept in mind.

ISPAD: International Society for Children and Adolescent Diabetes, T1D: type 1 diabetes diabetic ketoacidosis at the time of diagnosis is around $50 \%$, and this rate can reach as high as $80 \%$ in the eastern region of Turkey $(13,14)$. To address all these problems, the School Diabetes Program was initiated in 2010 as a part of the national diabetes program $(3,15)$. The program was developed as a joint protocol initiated by the Turkish Society of Pediatric Endocrinology and Diabetes in co-operation with the Ministry of Education and Ministry of Health. Since 2010, a training meeting has been organized in schools nationwide every World Diabetes Day. These educational meetings are attended by teachers, students and, in some schools, parents. A presentation and two films explaining diabetes and childhood obesity with a total running time of 24 minutes are downloaded from the website and watched by the participants. A video to raise public awareness was also prepared and broadcast on popular TV channels over a period of three months. The video shows the symptoms of diabetes in children, how a delay in diagnosis of diabetes may cause a severe clinical picture, that children with diabetes can lead a normal life like their peers and participate in all activities, and the importance of a support from teachers and other members of society (16).

The program includes training for teachers and recommendations on how to make schools friendlier places for children with diabetes, as well as guidelines for preventing obesity and diabetes. The program's goals are: Raising awareness of T1D through schools; early diagnosis; decreasing the frequency of diabetic ketoacidosis; better care for school children with T1D; promotion of healthy life choices; and raising awareness of obesity. The target groups are primarily those teachers with children with T1D in their classes as well as other teachers, members of the Children Diabetes Teams and municipal authorities and school administrators. The initial activities included: prominent display of the poster "Does my child have diabetes?" in 60,000 schools nationwide; distribution of educational leaflets on childhood diabetes; and online presentations were made available for teachers. Instructions were sent out to municipalities nationwide. With this program, pediatric endocrinology clinics across the country began sending program-branded letters to the teachers of children with T1D after they were discharged from hospital. The letters have been sent to the local health care units as well as the schools since 2018. Additionally, two short films and a website were prepared for teachers (16). The films are shown in schools every $14^{\text {th }}$ November (World Diabetes Day) (17).

In terms of nationwide school activities, a training platform had been created on the website to access educational material. On this platform, there are films, brochures and posters about diabetes and obesity. The film about diabetes 
describes what it is like for a child living with T1D using the own words. Particular emphasis was given to difficulties experienced in school and the expectations of children with T1D. The website is www.okuldadiyabet.com and this is a free, online education platform where all the abovementioned materials (Presentations, Films, Brochures, Posters) are available to download (16).

The program was updated in 2017 and the 'Task and Responsibility Document for Diabetes Care at School' came into force (18). This document covers the duties and responsibilities of families, school authorities, teachers, school nurses and pediatric endocrinology centers regarding diabetes care. With this new protocol, glucagon injection in the case of severe hypoglycemia was defined as a task for teachers, with the consent of the family. Additionally, a 'Guide for school exams for children with T1D', 'Individualized Diabetes Management Plan', and 'School Action Plan for children with T1D' were prepared and sent to schools.

In the last two years, there has been an emphasis on training for teachers and the presentations used in the training have been updated with new developments. Within the framework of teacher training, meetings between children with T1D and their families, teachers and diabetes teams have been organized in the larger cities of Turkey. These meetings have been held in Gaziantep, Adana, Samsun, Ankara, İstanbul and Eskişehir, and so far, they have been very effective.

The instructions were published in the Journal of Announcements of the Ministry of Education on October 14, 2020. Finally, 'The Diabetes at School Program $10^{\text {th }}$ Year Thank You Video' was prepared and shared in schools and on social media platforms (19).

\section{School Nursing and Diabetes Care in School}

The "Diabetes at School Program for School Nurses Istanbul Meeting" was held on 14 June 2019 and the meeting was attended by approximately 250 school nurses (most of whom were from İstanbul), members of the Public Health Nursing Association School Health Nursing commission, academician nurses working in the field of public health and child health, and mothers of children with T1D. The main messages of the meeting are summarized below.

- There are about 20,000 children with T1D in Turkey; these children spend most of their time at school; they are at risk of having impaired glucose control, particularly during school hours. School nurses play an important role in providing support to children with diabetes.

- Recently, there have been significant advances in the diagnosis and treatment of $\mathrm{T} 1 \mathrm{D}$. In particular, the use of continuous glucose monitoring systems and subcutaneous continuous insulin infusion (pump) systems that provide remote glucose monitoring facilitate diabetes management in children and reduce the burden on children with diabetes and their families. School nurses play a key role in the use of diabetes technologies in school for children under the age of 12 .

- The school nursing system, which is important for improving school health, is not sufficiently supported in Turkey.

- There is a need for official arrangements defining school nurses' employee personal rights, duties and responsibilities and their position vis-à-vis the law.

- Priority should be given to the establishment of a Turkeyspecific "School Nursing System", similar to that in developed countries.

\section{Regulations for Diabetes Care in the School Environment}

In Turkey's legal system, the ministries' own practices are regulated by directives prepared in the context of national laws. The most significant achievement of the Diabetes at School Program is the publication of the official regulations entitled "care and support of children with T1D at school" in October 2020 by the Ministry of National Education. These regulations were prepared by the National Pediatric Endocrinology and Diabetes Association and the document was then finalized by the officials of the Ministry of Education and Health, finally becoming legislation of the Ministry of National Education (18).

The main features of the new regulations are shown below.

- It provided regulations regarding the care of children with diabetes in the school environment in accordance with the recommendations of international organizations (including the International Child and Adolescent Diabetes Association) for the first time in Turkey.

- It contained the most up-to-date knowledge and experience concerning T1D.

- The duties of school staff, including teachers, families and diabetes teams, were described.

- The rights of children with diabetes, and in particular, the right to be treated like their peers, were guaranteed.

- The regulations consist of 18 items in total and detailed arrangements are given in Table 2.

These regulations have been sent by the Ministry of National Education to all school administrators. Our next task will be to improve the lives of children with diabetes in all schools 
Table 2. The 18 main topics of national regulations for diabetes care at school setting

The principles of diabetes care in the school setting

Preparing an "individual treatment plan at school" for every student with T1D

Preventing families from waiting unnecessarily at schools to administer insulin injections or carry out other tasks

Providing appropriate places for insulin injections

Support for insulin injection and glucagon administration

Support for the use of diabetes technologies in the school setting

Training of school staff concerning diabetes

Obtaining consent from school staff for the administration of insulin and glucagon when needed

Management of emergencies, especially hypoglycemia

Nutrition at school

Exercise, relationships with peers and participation in school life Exams and other situations

The responsibilities and duties of parents or caregivers

The responsibilities and duties of the school administration

The responsibilities and duties of teachers

The responsibilities and duties of school nurses

The responsibilities and duties of diabetes teams

Collaboration

T1D: type 1 diabetes

in Turkey and to work with an understanding that includes teachers in teams that support diabetes management. A distance learning module (which will be available online in 2021), consisting of short videos and texts providing practical information was prepared for teachers, school nurses, school administrators, other school staff and families. It is planned that this module will be placed in the distance learning infrastructure of the Ministry of National Education and that teachers and school staff who have students with diabetes in their schools will complete the "Diabetes Care in School" course and receive a certificate.

\section{Conclusion}

Strengthening diabetes care in schools in Turkey and elsewhere, while taking into account the needs and perspective of children with diabetes (qualitative research is needed on this issue) is still a work in progress $(2,6)$. Although there are successful programs in countries such as Canada, Australia, Sweden and Slovenia, there are only a few countries where diabetes care at school is defined as a national program $(7,20,21,22,23)$. The most important feature of the program in Turkey is that it is a sub-program of the National Diabetes Program, co-ordinated by the National Pediatric Endocrinology and Diabetes Association, but is essentially fully owned by the Ministries of National Education and Health. In this context, community health nurses affiliated with the Ministry of Health were provided to support many schools which did not have school nurses, and regional education programs were organized for this purpose. Again, within the scope of this program a 14-minute video explaining Diabetes in Children and Diabetes Care at School continues to be shown every year on World Diabetes Day, $14^{\text {th }}$ November.

Undoubtedly, despite the efforts of the last 10 years, problems continue in terms of awareness of T1D and providing the necessary support to children with diabetes during school hours. In a recent country-level study involving 55,677 teachers, school administrators and school nurses, $73 \%$ of the participants reported that they had heard about the Diabetes at School Program, $75 \%$ stated that their knowledge had increased thanks to this program, and $50 \%$ stated that their self-confidence had increased. The results of this study showed that nurses and the staff who had students with T1D in their classrooms/schools (women in particular), had higher scores (24). However, lower scores were noted in the northern and eastern regions of Turkey, where even in schools which had students with T1D, school staff did not have enough knowledge to determine carbohydrate count and bolus doses, and efforts were needed to continue a positive attitude change. Based on the results of this study and evaluations of the program, a nationwide distance education module for the Diabetes at School training has been prepared and it is planned to train all teachers, especially school staff who have students with diabetes in their schools, and to give a "participation certificate" to those who have completed this module.

Diabetes care at school should be delivered in support of families who say "I am actually his pancreas" (25), reducing their burden and maintaining the quality of uninterrupted diabetes care and should be the priority of all staff, especially pediatric diabetes teams. While the last consensus document of ISPAD on diabetes care at school is an important contribution to progress, the next step should be to recommend the "Diabetes at School Program" and the Regulations for Diabetes Care at School to all countries.

\section{Acknowledgments}

We would like to thank Alan J. Newson for English language editing of our manuscript.

\section{Ethics}

Peer-review: Internally peer-reviewed.

\section{Authorship Contributions}

Concept: Şükrü Hatun, Gül Yeşiltepe Mutlu, Tuğba Gökçe, Özkan Avcı, Nazan Yardım, Zehra Aycan, Feyza Darendeliler, 
Design: Şükrü Hatun, Gül Yeşiltepe Mutlu, Tuğba Gökçe, Özkan Avcı, Nazan Yardım, Zehra Aycan, Feyza Darendeliler, Data Collection or Processing: Şükrü Hatun, Analysis or Interpretation: Şükrü Hatun, Literature Search: Şükrü Hatun, Writing: Şükrü Hatun, Gül Yeşiltepe Mutlu, Tuğba Gökçe, Özkan Avcı, Nazan Yardım, Zehra Aycan, Feyza Darendeliler.

Financial Disclosure: The authors declared that this study received no financial support.

\section{References}

1. Lange K, Jackson C, Deeb L. Diabetes care in schools-the disturbing facts. Pediatr Diabetes 2009;10(Suppl 13):28-36.

2. Smith LB, Terry A, Bollepalli S, Rechenberg K. School-based management of pediatric type 1 diabetes: recommendations, advances, and gaps in knowledge. Curr Diab Rep 2019;19:37.

3. Hatun Ş. National childhood diabetes program activities in Turkey. J Clin Res Pediatr Endocrinol 2015;7:1-6.

4. Battelino T, Danne T, Bergenstal RM, Amiel SA, Beck R, Biester T, Bosi E, Buckingham BA, Cefalu WT, Close KL, Cobelli C, Dassau E, DeVries JH, Donaghue KC, Dovc K, Doyle F, Garg S, Grunberger G, Heller S, Heinemann L, Hirsch IB, Hovorka R, Jia W, Kordonouri O, Kovatchev B, Kowalski A, Laffel L, Levine B, Mayorov A, Mathieu C, Murphy HR, Nimri R, Nørgaard K, Parkin CG, Renard E, Rodbard D, Saboo B, Schatz D, Stoner K, Urakami T, Weinzimer SA, Phillip M. Clinical targets for continuous glucose monitoring data interpretation: Recommendations from the international consensus on time in range. Diabetes Care 2019;42:1593-1603. Epub 2019 Jun 8

5. Skipper N, Gaulke A, Sildorf SM, Eriksen TM, Nielsen NF, Svensson J. Association of type 1 diabetes with standardized test scores of danish school children. JAMA 2019;321:484-492.

6. Bratina N, Forsander G, Annan F, Wysocki T, Pierce J, Calliari LE, Pacaud D, Adolfsson P, Dovč K, Middlehurst A, Goss P, Goss J, Janson S, Acerini CL. ISPAD Clinical Practice Consensus Guidelines 2018: management and support of children and adolescents with type 1 diabetes in school. Pediatr Diabetes 2018;19(Suppl 27):287-301.

7. Bechara GM, Castelo Branco F, Rodrigues AL, Chinnici D, Chaney D, Calliari LEP, Reis Franco D. "KiDS and diabetes in schools" project: experience with an international educational intervention among parents and school professionals. Pediatr Diabetes 2018;19:756-760. Epub 2018 Mar 4

8. American Diabetes Association. 12. children and adolescents: standards of medical care in diabetes-2018. Diabetes Care 2018;41(Suppl 1):S126-S136.

9. American Association of Diabetes Educators. Management of children with diabetes in the school setting. Diabetes Educ 2014;40:116-121.

10. Yesilkaya E, Cinaz P, Andıran N, Bideci A, Hatun Ş, Sarı E, Türker T, Akgül Ö, Saldır M, Kılıçaslan H, Açıkel C, Craig ME. First report on the nationwide incidence and prevalence of type 1 diabetes among children in Turkey. Diabet Med 2017;34:405-410. Epub 2016 Feb 12

11. Haliloglu B, Akesen E, Atay Z, Guran T, Bereket A, Turan S. Diabetes related problems and diabetic controls among the school children with type 1 diabetes mellitus living in Istanbul. Pediatr Diabetes 2012;13:2728.
12. Aycan Z, Önder A, Çetinkaya S, Bilgili H, Yıldırım N, Baş VN, Peltek Kendirci HN, Ağladığlu SY. Assessment of the knowledge of diabetes mellitus among school teachers within the scope of the managing diabetes program at school. J Clin Res Pediatr Endocrinol 2012;4:199203. Epub 2012 Oct 2

13. Hatun Ş, Demirbilek H, Darcan Ş, Yüksel A, Binay C, Şimşek DG, Kara C, Çetinkaya E, Ünüvar T, Uçaktürk A, Tütüncüler F, Cesur Y, Bundak R, Sağlam H, Şimşek E, Bereket A; Turkish Pediatric Diabetes Research Group. Evaluation of therapeutics management patterns and glycemic control of pediatric type 1 diabetes mellitus patients in Turkey: a nationwide cross-sectional study. Diabetes Res Clin Pract 2016;119:3240. Epub 2016 Jun 27

14. Demirbilek H, Özbek MN, Baran RT. Incidence of type 1 diabetes mellitus in Turkish children from the southeastern region of the country: a regional report. J Clin Res Pediatr Endocrinol 2013;5:98-103.

15. Hatun S.. Diabetes program at schools in Turkey. J Clin Res Pediatr Endocrinol 2012;4:114-115

16. Okulda Diyebet Programı. Available from: https://okuldadiyabet.com/

17. T.C. Sağlık Bakanlığı. 14 Kasım Dünya Diyabet Günü Haftasında Okullarda Yapılacak Olan Diyabet ve Şişmanlık/Sağlıklı Beslenme Eğitim Videolarına ve Dökümanlara Buradan Ulaşabilirsiniz. Erişim tarihi: 03.11.2021. Available from: http://okulsagligi.meb.gov.tr/ www/14-kasim-dunya-diyabet-gunu-haftasinda-okullarda-yapilacakolan-diyabet-ve-sismanliksaglikli-beslenme-egitim-videolarina-vedokumanlara-buradan-ulasabilirsiniz/icerik/91

18. Millî Eğitim Bakanliği Tip 1 Diyabetli Öğrencilerin Okul/Kurumlarda Bakimi Ve Desteklenmesi Hakkinda Yönerge. Last Accessed Date: 10.11.2021. Available from: https://www.arkadasimdiyabet.com/ wpcontent/uploads/4_5782887848738817844.pdf

19. Okulda Diyabet Programı 10. Yıl Teşekkür Videosu. Available from: http://www.cocukendokrindiyabet.org/uploads/video/ODPOnuncuYil. mp4

20. Evans-Atkinson T, Fung A, Antunes Silvestre A, Crozier T, Hursh B. Evaluation of a province-wide type 1 diabetes care plan for children in the school setting. Can J Diabetes 2021;45:15-21. Epub 2020 May 7

21. Sarnblad S, Akesson K, Fernstrom L, Ilvered R, Forsander G. Improved diabetes management in Swedish schools: results from two national surveys. Pediatr Diabetes 2017;18:463-469. Epub 2016 Jul 29

22. Diabetes in School. Available from: https://www.diabetesinschools. com.aul

23. Bratina N, Battelino T. Insulin pumps and continuous glucose monitoring (CGM) in preschool and school-age children: how schools can integrate technology. Pediatr Endocrinol Rev 2010;7(Suppl 3):417421.

24. Gökçe T, Sakarya S, Muradoğlu S, Mutlu GY, Can E, Cemhan K, Kurtulmuş MF, Gülşen M, Aycan Z, Darendeliler F, Ülger Ö, Bulanık M, Yardım N, Hatun Ş. An evaluation of the knowledge and attitudes of school staff related to diabetes care at school: the 10th year of the "diabetes program at school" in Turkey. Pediatr Diabetes 2021;22:233240. Epub 2020 Nov 30

25. Commissariat PV, Harrington KR, Whitehouse AL, Miller KM, Hilliard ME, Van Name M, DeSalvo DJ, Tamborlane WV, Anderson BJ, DiMeglio LA, Laffel LM. "I'm essentially his pancreas": parent perceptions of diabetes burden and opportunities to reduce burden in the care of children <8years old with type 1 diabetes. Pediatr Diabetes 2020;21:377-383. Epub 2019 Dec 16 